\title{
Wheat yield in the Cerrado as affected by nitrogen fertilization and inoculation with Azospirillum brasilense
}

\author{
Fernando Shintate Galindo(1), Marcelo Carvalho Minhoto Teixeira Filho(1), Salatiér Buzetti(1), \\ José Mateus Kondo Santini(1), Cleiton José Alves ${ }^{(1)}$ and Mariana Gaioto Ziolkowski Ludkiewicz ${ }^{(1)}$
}

\begin{abstract}
(1)Universidade Estadual Paulista Júlio de Mesquita Filho, Faculdade de Engenharia, Avenida Brasil, no 56, Centro, CEP 15385-000 Ilha Solteira, SP, Brazil. E-mail: fs.galindo@bol.com.br, mcmteixeirafilho@agr.feis.unesp.br, sbuzetti@agr.feis.unesp.br, santinijmk@gmail.com, cleiton.agr.feis@gmail.com, mariana.gaioto@gmail.com
\end{abstract}

\begin{abstract}
The objective of this work was to evaluate the effect of inoculation with Azospirillum brasilense, associated with $\mathrm{N}$ rates and sources, in soil of the Cerrado (Brazilian savanna), on the grain yield of irrigated wheat (Triticum aestivum). The experiment was carried out under a no-tillage system in a Typic Haplustox. The experimental design was randomized complete blocks with four replicates, in a $2 \times 5 \times 2$ factorial arrangement: two $\mathrm{N}$ sources (urea and urea with NBPT urease inhibitor); five $\mathrm{N}$ rates applied as topdressing $(0,50,100$, 150 , and $200 \mathrm{~kg} \mathrm{ha}^{-1}$ ); and with or without seed inoculation with $A$. brasilense. The increase in the $\mathrm{N}$ rates positively affected spike length, number of spikelets and of grains per spike, number of spikes per meter, $\mathrm{N}$ accumulation in the straw, leaf chlorophyll content, and grain yield of irrigated wheat, regardless of the use of NBPT urease inhibitor with conventional urea. Singly, inoculation with A. brasilense does not affect production components and grain yield, despite the increase in $\mathrm{N}$ content in wheat straw. The inoculation with A. brasilense, associated with the application of $140 \mathrm{~kg} \mathrm{ha}^{-1} \mathrm{~N}$, provides the highest grain yield of irrigated wheat cropped after corn in low-altitude Cerrado.
\end{abstract}

Index terms: Triticum aestivum, biological nitrogen fixation, nitrogen sources, no-tillage system, urease inhibitor.

\section{Produtividade de trigo no Cerrado em função da adubação nitrogenada e da inoculação com Azospirillum brasilense}

Resumo - O objetivo deste trabalho foi avaliar o efeito da inoculação com Azospirillum brasilense, associada a doses e fontes de N, em solo de Cerrado, sobre a produtividade de grãos de trigo (Triticum aestivum) irrigado. $\mathrm{O}$ experimento foi desenvolvido em sistema plantio direto, em Latossolo Vermelho distrófico. Utilizou-se o delineamento experimental de blocos ao acaso, com quatro repetições, em arranjo fatorial 2x5x2: duas fontes de $\mathrm{N}$ (ureia e ureia com inibidor da urease NBPT); cinco doses de $\mathrm{N}$ em cobertura $(0,50$, 100,150 e $200 \mathrm{~kg} \mathrm{ha}^{-1}$ ); e com ou sem inoculação das sementes com A. brasilense. O aumento nas doses de $\mathrm{N}$ apresentou efeito positivo no comprimento de espiga, número de espiguetas e de grãos por espiga, número de espigas por metro, acúmulo de $\mathrm{N}$ na palha, conteúdo de clorofila na folha e produtividade de grãos de trigo irrigado, independentemente do uso de inibidor de urease NBPT com ureia. Isoladamente, a inoculação com A. brasilense não afeta os componentes de produção e a produtividade de grãos, apesar de incrementar o $\mathrm{N}$ na palhada de trigo. A inoculação com A. brasilense, associada à aplicação de $140 \mathrm{~kg}^{-1} \mathrm{~d}^{-1}$ de $\mathrm{N}$, propicia as maiores produtividades de grãos de trigo irrigado, cultivado após milho em Cerrado de baixa altitude.

Termos para indexação: Triticum aestivum, fixação biológica de nitrogênio, fontes de nitrogênio, sistema plantio direto, inibidor da urease.

\section{Introduction}

In the 2015 harvest season in Brazil, wheat (Triticum aestivum L.) was grown in 2.5 million hectares of land, where 6.7 million tons of grain were produced, with an average yield of $2.7 \mathrm{Mg} \mathrm{ha}^{-1}$. Although the Southern region of the country is responsible for approximately $90 \%$ of the national production of wheat, this cereal is being gradually introduced into the Cerrado region (Brazilian savanna) using either irrigated or dry farming (Acompanhamento..., 2015).

Nitrogen fertilization is used to obtain high grain yields for this cereal. However, according to Lara 
Cabezas et al. (2000), there is a reduction of about 10 $\mathrm{kg} \mathrm{ha}^{-1}$ in corn grain yield for each $1 \%$ volatilized $\mathrm{N}$. In this context, the efficiency of $\mathrm{N}$ fertilization can be increased with the inhibitor N-(n-butyl) thiophosphoric triamide (NBPT), which can delay the hydrolysis of urea and significantly reduce the loss of ammonia in regions with a predominance of high temperatures, including the low-altitude Cerrado region (Valderrama et al., 2014).

Most studies conducted in Brazil showed that urea combined with a urease inhibitor as well as conventional urea have a similar efficiency in $\mathrm{N}$ nutrition and grain yield (Cantarella et al., 2008): the inhibitory activity of urease does not effectively reduce the losses by ammonia volatilization, which occurs when urea is applied to the soil surface. This can be explained by the fact that the action of NBPT depends on: environmental conditions, such as temperature and rainfall; physical and chemical characteristics of acid and weathered soils; and cultivation system, which is the no-tillage system with straw (a source of urease) on soil surface in most of the Cerrado region.

Another possibility is the use of bacterial inoculants, which promote plant growth and increase productivity. Brazil has a tradition of research in biological $\mathrm{N}$ fixation (BNF) using Azospirillum spp. in graminaceous plants. However, until recently, no commercial inoculants with this bacterial strain were available in Brazil (Hungria, 2011). The observed effects after inoculation were increased uptake of water and minerals and increased tolerance to stress such as drought and salinity, which increased plant robustness and yield (Bashan et al., 2004). Barassi et al. (2008) reported an improvement in the photosynthetic parameters of leaves, including chlorophyll content and stomatal conductance, increased proline content in aerial parts and roots, improvement in water potential, increased water content of the apoplast, increased elasticity of the cellular wall, and greater plant biomass.

Dobbelaere et al. (2003) observed that positive responses to inoculation with Azospirillum brasilense were obtained even when cultures were grown in soils with high levels of available N, which indicates that plant responses might be due to the fixed $\mathrm{N}$ and the production of plant growth hormones, including cytokinin, gibberellin, and indoleacetic acid. Lemos et al. (2013) evaluated five wheat cultivars and observed a positive interaction between $A$. brasilense and $\mathrm{N}$ fertilization only for the CD 150 cultivar. Increases in the efficiency of $\mathrm{N}$ fertilization combined with inoculation with A. brasilense were reported by Galindo et al. (2016) for the productivity of corn grains in the Cerrado region.

Despite these benefits, increase in wheat grain productivity was not always observed after seed inoculation with Azospirillum ssp., which indicates the need for more research on this topic and for a better definition of the amount of mineral $\mathrm{N}$ that should be applied to achieve optimal BNF and grain yield (Galindo et al., 2016). It is also important to assess whether urea with a urease inhibitor (NBPT) is less harmful to BNF in graminaceous plants owing to the slower release of $\mathrm{N}$.

The objective of this work was to evaluate the effect of inoculation with $A$. brasilense, associated with $\mathrm{N}$ rates and sources, in soil of the Cerrado, on the grain yield of irrigated wheat.

\section{Materials and Methods}

The study was conducted at the experimental station of Fazenda de Ensino, Pesquisa e Extensão of Faculdade de Engenharia, of Universidade Estadual Paulista Júlio de Mesquita Filho, located in the municipality of Selvíria, in the state of Mato Grosso do Sul, Brazil $\left(20^{\circ} 22^{\prime} \mathrm{S}, 51^{\circ} 22^{\prime} \mathrm{W}\right.$, at an altitude of $\left.335 \mathrm{~m}\right)$ in 2014 and 2015. The soil in the experimental area was classified as a clayey Latossolo Vermelho distrófico (Santos et al., 2013), i.e., a Typic Haplustox. The area has been cultivated with annual crops for more than 27 years, and the no-tillage system has been used for the past 10 years. Since the crop planted before wheat sowing was corn in both years of evaluation, only graminaceous plants were cultivated in the 2 years before the study. The average temperature was $23.5^{\circ} \mathrm{C}$, the annual average precipitation was $1,370 \mathrm{~mm}$, and the annual average relative air humidity was $70-80 \%$ (Figure 1). The climate type is Aw, according to Köppen's classifications, defined as humid tropical with rainy season in summer and dry in winter.

The experimental design was randomized complete blocks with four replicates, in a $2 \times 5 \times 2$ factorial arrangement: two $\mathrm{N}$ sources - conventional urea, $45 \% \mathrm{~N}$; and NBPT (Super N commercial fertilizer), conventional urea with NBPT urease inhibitor; five $\mathrm{N}$ rates $-0,50,100,150$, and $200 \mathrm{~kg} \mathrm{ha}^{-1}$; and $\mathrm{N}$ 
application using the broadcasting technique, with or without seed inoculation with $A$. brasilense. The experimental plots were composed of 12 lines with $6 \mathrm{~m}$ in length and spaced at a $0.17 \mathrm{~m}$ distance, and the useful area of the plot comprised the central eight lines, excluding $0.5 \mathrm{~m}$ from the ends.

The herbicides used in the experimental areas were glyphosate (1,800 $\mathrm{g} \mathrm{ha}^{-1}$ a.i.) and 2,4-D (670 $\mathrm{g} \mathrm{ha}^{-1}$ a.i.) for desiccation; these products were applied 2 weeks before wheat sowing in 2014 and 2015. The chemical attributes of the topsoil (depth of $0.00-0.20 \mathrm{~m}$ ) were determined in 2014 before the initiation of the experiment, following the methodology proposed by Raij et al. (2001). The following results were obtained: $13 \mathrm{mg} \mathrm{dm}^{-3} \mathrm{P}$ (resin); $6 \mathrm{mg} \mathrm{dm}^{-3} \mathrm{~S}_{-\mathrm{SO}_{4}} ; 23 \mathrm{~g} \mathrm{dm}^{-3}$ organic matter; $\mathrm{pH} 4.8\left(\mathrm{CaCl}_{2}\right) ; 2.6,13.0,8.0$, and $42.0 \mathrm{mmol}_{\mathrm{c}} \mathrm{dm}^{-3} \mathrm{~K}, \mathrm{Ca}, \mathrm{Mg}$, and $\mathrm{H}+\mathrm{Al}$, respectively; 5.9, 30.0, 93.9, and $1.0 \mathrm{mg} \mathrm{dm}^{-3} \mathrm{Cu}, \mathrm{Fe}, \mathrm{Mn}$, and $\mathrm{Zn}$ (DTPA), respectively; $0.24 \mathrm{mg} \mathrm{dm}^{-3} \mathrm{~B}$ (hot water); and base saturation of $36 \%$.
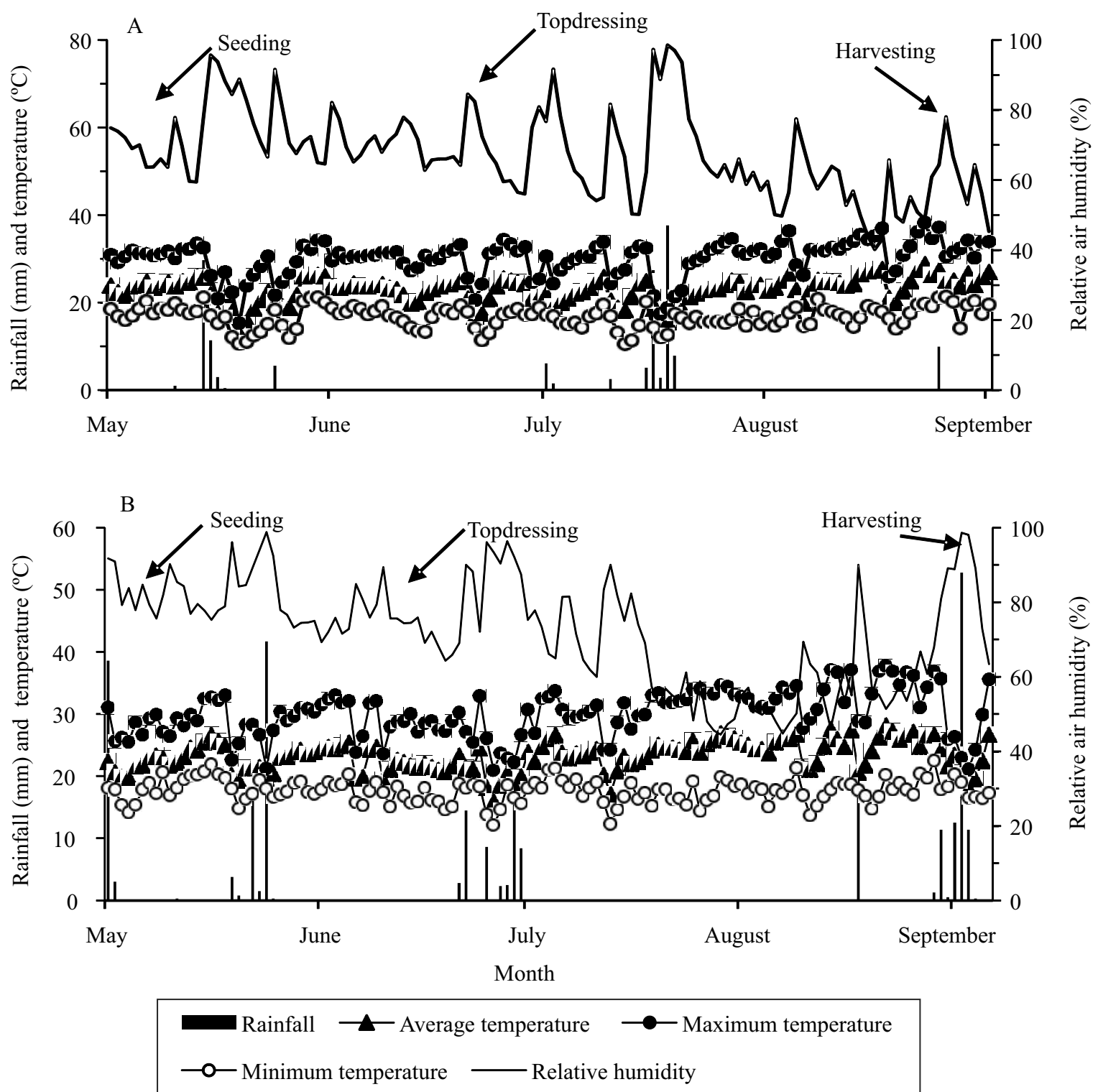

Figure 1. Rainfall, relative air humidity, and maximum, average and minimum temperatures during wheat cultivation from May to September 2014 (A) and May to September 2015 (B), obtained from the weather station located at Fazenda de Ensino, Pesquisa e Extensão of Universidade Estadual Paulista Júlio de Mesquita Filho, in the municipality of Selvíria, in the state of Mato Grosso do Sul, Brazil. 
Based on the results of soil analysis and the need to increase base saturation to $70 \%$, as recommended by Cantarella et al. (1997), $2.5 \mathrm{Mg} \mathrm{ha}^{-1}$ of dolomitic limestone (ECCE 88\%) were applied to the soil 65 days before sowing wheat in 2014. Furthermore, based on the results of soil analysis and culture requirements, 28, 98 , and $56 \mathrm{~kg} \mathrm{ha}^{-1} \mathrm{~N}, \mathrm{P}_{2} \mathrm{O}_{5}$, and $\mathrm{K}_{2} \mathrm{O}$, respectively, were supplied in 2014 as in 2015 for sowing fertilization.

Inoculation of wheat seeds with strains AbV5 and AbV6 of $A$. brasilense (to achieve a density of $2 \times 10^{8}$ $\mathrm{CFU} \mathrm{mL} \mathrm{m}^{-1}$ ) was performed using $300 \mathrm{~mL}$ of the liquid inoculant Azototal (Total Biotecnologia, Curitiba, PR, Brazil) per hectare of wheat seed. The inoculant was mixed with the seeds in the shade using a clean mixer $1 \mathrm{~h}$ before sowing after treatment of the seeds with insecticide and fungicide. For seed treatment, the fungicides carbendazim + thiram $(45 \mathrm{~g}+105 \mathrm{~g}$ a.i. per $100 \mathrm{~kg}$ of seed) and the insecticides imidacloprid + thiodicarb $(45 \mathrm{~g}+135 \mathrm{~g}$ a.i. per $100 \mathrm{~kg}$ of seed) were used.

The experimental area was managed under a notillage system. The area was irrigated using a center pivot sprinkler system, with a mean water depth of $14 \mathrm{~mm}$ and an irrigation interval of approximately 72 hours in both cultures. The cultivar used was $116 \mathrm{CD}$ with mechanical seeding on 5/16/2014 and 5/15/2015 at a density of 80 seeds per meter. The seedlings emerged 6 and 5 days after sowing, on 5/22/2014 and 5/20/2015, respectively.

The growth of weeds was managed with the application of the herbicide metsulfuron-methyl ( $3 \mathrm{~g} \mathrm{ha}^{-1}$ a.i.) 20 days after emergence (DAE) of wheat in both seasons. Nitrogen fertilization was performed manually on $6 / 26 / 2014$ and 6/22/2015 (that is, 35 and 32 DAE respectively), and the fertilizer was spread on the soil surface without incorporation on the sides and at approximately $8 \mathrm{~cm}$ from the sowing lines to avoid contact with the plants. After cover fertilization, the area was irrigated by sprinkling (depth of $14 \mathrm{~mm}$ ) at night to minimize losses by volatilization of ammonia, which is common in irrigated wheat. The plants were harvested manually in both seasons at $110 \mathrm{DAE}$, on 9/9/2014 and 9/8/2015 respectively.

Plant height at maturity (defined as the distance (m) from the ground level to the apex of the spike) was determined. The following characteristics were also evaluated in ten spikes at harvest: spike length, measured from the apex to the base of the spike; number of spikelets, by counting all spikelets with grains; number of grains per spike, by counting the number of grains in each spike in each experimental unit; and number of defective grains, by calculating the number of undeveloped spikelets per spike. The $\mathrm{N}$ accumulation was determined in the wheat straw at the end of the production cycle. Nitrogen was measured after plant collection in three $0.5-\mathrm{m}^{2}$ experimental areas per plot after drying, weighing, grinding, and sulfuric digestion of the seeds following the methodology proposed by Malavolta et al. (1997). Subsequently, $\mathrm{N}$ accumulation was calculated in $\mathrm{kg} \mathrm{ha}^{-1}$. The other evaluated parameters were: the leaf chlorophyll index (LCI), which was indirectly measured in the middle third portion of the flag leaf in five plants per plot in the flowering period using a digital chlorophyll meter model CFL 1030 (Falker Automação Agrícola Ltda., Porto Alegre, RS, Brazil); number of spikes per meter, by counting the number of spikes at harvest on a 1-m plant row in the useful area of each parcel; hectoliter mass, corresponding to the mass of wheat grains in a 100-L container determined on a $1 / 4$ scale after adjusting the water content of the grains to $13 \%$ (wet basis); mass of 100 grains, measured in a 0.01 -g precision scale at $13 \%$ (wet basis); and yield, determined by counting the spikes of plants present in the four useful lines of each plot. After mechanical tracking, the grains were quantified, and the data were converted into $\mathrm{kg} \mathrm{ha}^{-1}$ at $13 \%$ (wet basis).

The results were subjected to the analysis of variance and to Tukey's test, at 5\% probability, for the comparison of the average yields obtained with the different $\mathrm{N}$ sources and with or without inoculation with $A$. brasilense. The regression equations were adjusted to the effect of $\mathrm{N}$ rates using the Sisvar software (Ferreira, 2011).

\section{Results and Discussion}

The increase in the $\mathrm{N}$ rates significantly affected the number of spikelets per spike in the 2015 harvest and the spike length, number of grains per spikelet, and number of grains per spike in 2014 and 2015 (Figure 2). There were adjustments to increasing linear functions for spike length in 2014 and 2015 (Figure 2 $\mathrm{A}$ and $\mathrm{B}$ ) and for the number of spikelets (Figure 2 C) and number of grains per spike in 2014 (Figure 2 D). The data fitted a quadratic function to the number of grains per spike in the 2015 harvest with a point of 

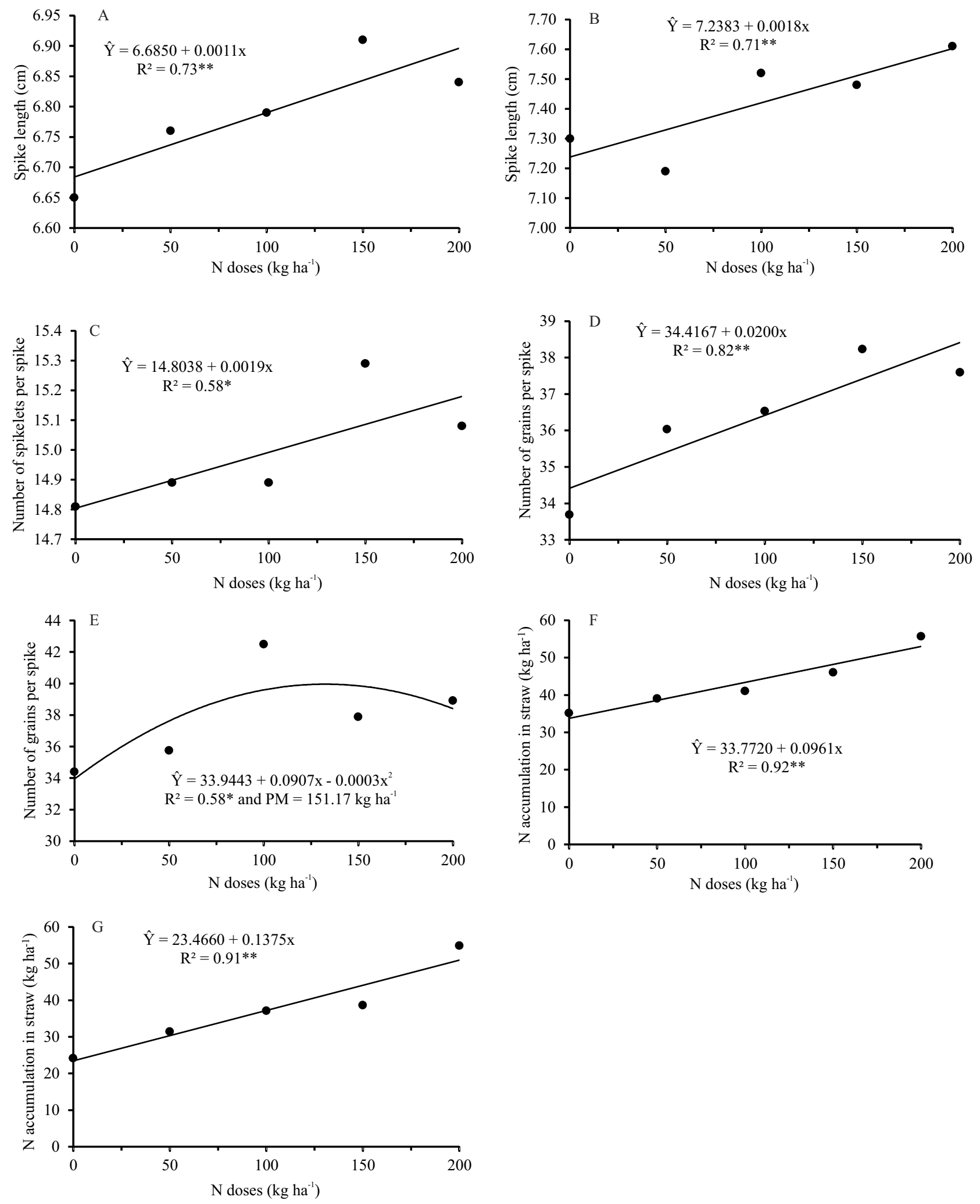

Figure 2. Spike length in 2014 (A) and 2015 (B), number of spikelets per spike in 2015 (C), number of grains per spike in 2014 (D) and 2015 (E), N accumulation in wheat straw in 2014 (F) and 2015 (G), in function of N rates. ** and *Significant at 1 and $5 \%$ probability, respectively. 
maximum rate at $151 \mathrm{~kg} \mathrm{ha}^{-1} \mathrm{~N}$ (Figure $2 \mathrm{E}$ ). However, plant height and the number of defective grains per spike were not affected by the increase in $\mathrm{N}$ rates (Table 1) regardless of the $\mathrm{N}$ source and inoculation with $A$. brasilense. Therefore, it was observed that the inoculation of diazotrophic bacteria associated with high $\mathrm{N}$ rates did not affect the growth of the aerial part of the plant, similarly to results reported in other studies (Hungria, 2010).

With regard to spike length, Teixeira Filho et al. (2008) evaluated cultivars IAC 370 and IAC 24 at different plant densities and did not observe any effect of the $\mathrm{N}$ rates. Rodrigues et al. (2014) evaluated the agronomic characteristics of wheat grown in a greenhouse (presence of $A$. brasilense, humic acids, and $\mathrm{N}$ content) and observed a linear increase in spike length with an increase in $\mathrm{N}$ levels, which is consistent with results reported in the present work. There was no association between inoculation with $A$. brasilense and $\mathrm{N}$ rates. However, there was a positive correlation between the increases of $\mathrm{N}$ fertilization and the spike length.

Plant height was not affected by the $\mathrm{N}$ content (Table 1), as observed by Teixeira Filho et al. (2008) at the rates of $0,30,60,90,120$, and $150 \mathrm{~kg} \mathrm{ha}^{-1} \mathrm{~N}$ and by Teixeira Filho et al. (2010) at the rates of 0, 50, 100,
150 , and $200 \mathrm{~kg} \mathrm{ha}^{-1} \mathrm{~N}$. By contrast, Pietro-Souza et al. (2013) found that the $\mathrm{N}$ rates affected plant height in the 'BRS Guamirim' wheat crop. Theago et al. (2014) analyzed the rates of $0,50,100,150$, and $200 \mathrm{~kg} \mathrm{ha}^{-1} \mathrm{~N}$ and also observed that $\mathrm{N}$ affected plant height at a rate of up to $147 \mathrm{~kg} \mathrm{ha}^{-1}$.

The $\mathrm{N}$ rates also affected the number of grains per spike. Similar results were obtained by Theago et al. (2014), who reported that the increase in N levels (in topdressing) at a rate of up to $128 \mathrm{~kg} \mathrm{ha}^{-1}$ produced the largest number of grains per spike and spikes per meter, irrespective of the $\mathrm{N}$ source used.

The $\mathrm{N}$ sources did not affect the plant height, spike length, number of spikelets per spike, number of grains per spike, and number of defective grains per spike in the harvests of 2014 and 2015 (Table 1). Megda et al. (2009), Teixeira Filho et al. (2010), and Theago et al. (2014) obtained similar results when using ammonium sulfonitrate, ammonium sulfate, and urea as $\mathrm{N}$ sources in irrigated wheat cultivated in the low-altitude Cerrado region.

Inoculation with $A$. brasilense did not affect the spike length, number of spikelets per spike, number of grains per spike, and number of defectives grains per spike in 2014 and 2015 and plant height in 2015 (Table 1). Similar results were found by Ferreira et al.

Table 1. Plant height, spike length, number of spikelets, number of grains per spike, number of defective grains per spike and $\mathrm{N}$ accumulation in straw of wheat (Triticum aestivum), affected by $\mathrm{N}$ rates and sources, with or without inoculation with Azospirillum brasilense (2014 and 2015) ${ }^{(1)}$.

\begin{tabular}{|c|c|c|c|c|c|c|c|c|c|c|c|c|}
\hline \multirow[t]{2}{*}{ Treatment } & \multicolumn{2}{|c|}{$\begin{array}{l}\text { Plant height } \\
(\mathrm{cm})\end{array}$} & \multicolumn{2}{|c|}{$\begin{array}{l}\text { Spike length } \\
(\mathrm{cm})\end{array}$} & \multicolumn{2}{|c|}{$\begin{array}{c}\text { No. of spikelets } \\
\text { per spike }\end{array}$} & \multicolumn{2}{|c|}{$\begin{array}{l}\text { No. of grains } \\
\text { per spike }\end{array}$} & \multicolumn{2}{|c|}{$\begin{array}{l}\text { No. of defective } \\
\text { grains per spike }\end{array}$} & \multicolumn{2}{|c|}{$\begin{array}{l}\mathrm{N} \text { accumulation in } \\
\text { straw }\left(\mathrm{kg} \mathrm{ha}^{-1}\right)\end{array}$} \\
\hline & 2014 & 2015 & 2014 & 2015 & 2014 & 2015 & 2014 & 2015 & 2014 & 2015 & 2014 & 2015 \\
\hline \multicolumn{13}{|l|}{$\mathrm{N}$ rates $\left(\mathrm{kg} \mathrm{ha}^{-1}\right)$} \\
\hline 0 & 84.89 & 75.51 & 6.65 & 7.30 & 14.81 & 17.38 & 33.69 & 34.40 & 1.27 & 1.82 & 35.14 & 24.12 \\
\hline 50 & 86.54 & 77.00 & 6.76 & 7.19 & 14.89 & 16.42 & 36.03 & 35.75 & 1.23 & 1.65 & 39.03 & 31.39 \\
\hline 100 & 85.26 & 75.81 & 6.79 & 7.52 & 14.89 & 17.75 & 36.53 & 42.48 & 1.18 & 1.43 & 41.04 & 37.08 \\
\hline 150 & 87.10 & 76.53 & 6.91 & 7.48 & 15.29 & 17.50 & 38.23 & 37.88 & 1.12 & 1.70 & 46.05 & 38.59 \\
\hline 200 & 85.09 & 76.87 & 6.84 & 7.61 & 15.08 & 17.58 & 37.59 & 38.91 & 1.19 & 1.40 & 55.66 & 54.89 \\
\hline \multicolumn{13}{|l|}{$\mathrm{N}$ sources } \\
\hline Urea & $86.34 \mathrm{a}$ & $76.56 \mathrm{a}$ & $6.81 \mathrm{a}$ & $7.44 \mathrm{a}$ & $14.93 \mathrm{a}$ & $17.49 \mathrm{a}$ & $36.08 \mathrm{a}$ & $38.60 \mathrm{a}$ & $1.21 \mathrm{a}$ & $1.69 \mathrm{a}$ & $43.22 \mathrm{a}$ & $38.87 \mathrm{a}$ \\
\hline NBPT & $85.21 \mathrm{a}$ & $76.13 a$ & $6.77 \mathrm{a}$ & $7.39 \mathrm{a}$ & $15.06 \mathrm{a}$ & $17.17 \mathrm{a}$ & $36.75 a$ & $37.17 \mathrm{a}$ & $1.19 \mathrm{a}$ & $1.51 \mathrm{a}$ & $43.55 \mathrm{a}$ & $35.56 \mathrm{a}$ \\
\hline$\underline{\operatorname{LSD}}(5 \%)$ & 1.38 & 2.50 & 0.09 & 0.23 & 0.26 & 0.66 & 1.48 & 2.70 & 0.11 & 0.30 & 6.93 & 4.91 \\
\hline \multicolumn{13}{|l|}{ Inoculation } \\
\hline With Azospirillum & $85.03 \mathrm{~b}$ & $75.67 \mathrm{a}$ & $6.81 \mathrm{a}$ & $7.53 \mathrm{a}$ & $14.93 \mathrm{a}$ & $17.43 \mathrm{a}$ & $36.43 a$ & $36.73 \mathrm{a}$ & $1.18 \mathrm{a}$ & $1.68 \mathrm{a}$ & $48.54 \mathrm{a}$ & $39.80 \mathrm{a}$ \\
\hline Without Azospirillum & $86.53 \mathrm{a}$ & $77.02 \mathrm{a}$ & $6.77 \mathrm{a}$ & 7.31a & $15.06 \mathrm{a}$ & $17.22 \mathrm{a}$ & $36.40 \mathrm{a}$ & $39.04 \mathrm{a}$ & $1.22 \mathrm{a}$ & $1.52 \mathrm{a}$ & $38.23 b$ & $34.82 \mathrm{~b}$ \\
\hline $\operatorname{LSD}(5 \%)$ & 1.38 & 2.50 & 0.09 & 0.23 & 0.26 & 0.66 & 1.48 & 2.70 & 0.11 & 0.30 & 6.93 & 4.91 \\
\hline Overall mean & 85.78 & 76.34 & 6.79 & 7.42 & 14.99 & 17.33 & 36.42 & 37.88 & 1.20 & 1.60 & 43.38 & 37.31 \\
\hline Coefficient of variation ( $\%)$ & 3.58 & 6.26 & 3.12 & 5.94 & 3.93 & 7.30 & 7.76 & 13.65 & 20.01 & 35.92 & 30.56 & 25.26 \\
\hline
\end{tabular}

${ }^{(1)}$ Means followed by equal letters, in the columns, do not differ by Tukey's test, at 5\% probability. LSD, lower significant difference. 
(2014) and Galindo et al. (2015) with the inoculation of wheat leaves with $A$. brasilense in the Cerrado region. These authors found that bacterial inoculation did not affect the plant height, number of grains per spike, number of spikelets per spike, number of defective grains, and number of spikes per meter. Nunes et al. (2015) also found that the number of grains per spike was not affected by inoculation with $A$. brasilense in soils with low and high $\mathrm{N}$ availability. In the present work, however, the inoculated plants were shorter than non-inoculated plants in the 2014 harvest (Table 1).

Higher $\mathrm{N}$ rates increased $\mathrm{N}$ accumulation linearly in the wheat straw in the two crop years (Figure $2 \mathrm{~F}$ and G). However, there was no significant difference in $\mathrm{N}$ accumulation between conventional urea and conventional urea combined with NBPT urease inhibitor (Table 1). The inoculation with $A$. brasilense also caused a higher $\mathrm{N}$ accumulation in the wheat straw in both crop years, confirming the effect of associating this bacteria with graminaceous plants on BNF. Lemos et al. (2013) analyzed five wheat cultivars and found that inoculation with $A$. brasilense increased the $\mathrm{N}$ content of the aerial parts of the CD 108 cultivar.

The $\mathrm{N}$ rates did not affect the mass of 100 grains and hectoliter mass (Table 2). Similar results were reported by Teixeira Filho et al. (2008) and Theago et al. (2014), who observed that the $\mathrm{N}$ rates did not affect these parameters, and by Nunes et al. (2015), who found that the $\mathrm{N}$ rates (in topdressing) did not affect the mass of 1,000 grains in areas with high $\mathrm{N}$ availability. Frank \& Bauer (1996) observed that, in the period between the emergence of seedlings and the differentiation of panicles, $\mathrm{N}$ deficiency reduced the mass of 1,000 grains. In the present work, none of the evaluated crops presented $\mathrm{N}$ deficiency probably because of the irrigated wheat crop and because the number of grains per spike increased as affected by the increasing $\mathrm{N}$ rates, which enhanced the competition for photoassimilates in the spike (Teixeira Filho et al., 2010) but was not enough to reduce the grain mass.

There was a significant interaction between the $\mathrm{N}$ rates and bacterial inoculation for LCI in 2014 (Table 3). At the rate of $200 \mathrm{~kg} \mathrm{ha}^{-1} \mathrm{~N}$, the inoculated treatments showed the greatest LCI. The LCI was adjusted to an increasing linear function for $\mathrm{N}$ rates in the inoculated treatments and to a quadratic function in the noninoculated treatments, with the point of maximum rate at $101 \mathrm{~kg} \mathrm{ha}^{-1} \mathrm{~N}$ (Figure $3 \mathrm{~A}$ ). In the 2015 harvest, the LCI increased linearly with increasing $\mathrm{N}$ levels (Figure $3 \mathrm{~B})$. Other authors also reported an increase in the LCI

Table 2. Leaf chlorophyll index (LCI), number of spikes per meter, hectoliter mass, mass of 100 grains, and grain yield of wheat (Triticum aestivum) affected by $\mathrm{N}$ rates and sources, with or without inoculation with Azospirillum brasilense (2014 and 2015$)^{(1)}$.

\begin{tabular}{|c|c|c|c|c|c|c|c|c|c|c|}
\hline \multirow[t]{2}{*}{ Treatment } & \multicolumn{2}{|c|}{ LCI } & \multicolumn{2}{|c|}{$\begin{array}{c}\text { Number of spikes } \\
\text { per meter }\end{array}$} & \multicolumn{2}{|c|}{$\begin{array}{l}\text { Hectoliter mass } \\
\quad\left(\mathrm{kg} 100 \mathrm{~L}^{-1}\right)\end{array}$} & \multicolumn{2}{|c|}{$\begin{array}{l}\text { Mass of } 100 \\
\text { grains }(\mathrm{g})\end{array}$} & \multicolumn{2}{|c|}{$\begin{array}{l}\text { Grain yield } \\
\qquad\left(\mathrm{kg} \mathrm{ha}^{-1}\right)\end{array}$} \\
\hline & 2014 & 2015 & 2014 & 2015 & 2014 & 2015 & 2014 & 2015 & 2014 & 2015 \\
\hline \multicolumn{11}{|l|}{$\mathrm{N}$ rates $\left(\mathrm{kg} \mathrm{ha}^{-1}\right)$} \\
\hline 0 & 49.89 & 50.92 & 81.00 & 69.17 & 84.86 & 87.23 & 3.83 & 4.20 & 2,269 & 1,906 \\
\hline 50 & 55.41 & 52.31 & 85.94 & 76.50 & 84.74 & 86.83 & 3.84 & 4.10 & 3,004 & 3,027 \\
\hline 100 & 56.17 & 54.50 & 95.00 & 84.42 & 84.73 & 87.42 & 3.96 & 4.19 & 3,132 & 3,363 \\
\hline 150 & 58.77 & 55.23 & 97.88 & 73.75 & 84.78 & 86.14 & 3.93 & 4.13 & 3,266 & 3,167 \\
\hline 200 & 57.91 & 56.16 & 92.13 & 74.50 & 84.77 & 85.96 & 3.88 & 4.12 & 3,161 & 3,263 \\
\hline \multicolumn{11}{|l|}{$\mathrm{N}$ sources } \\
\hline Urea & $54.72 \mathrm{a}$ & $52.66 \mathrm{~b}$ & $87.73 a$ & $75.50 \mathrm{a}$ & $84.86 a$ & $87.14 \mathrm{a}$ & $3.89 \mathrm{a}$ & $4.17 \mathrm{a}$ & $2,959 a$ & $2,930 \mathrm{a}$ \\
\hline NBPT & $56.53 a$ & $54.99 \mathrm{a}$ & $93.05 \mathrm{a}$ & $75.83 a$ & $84.70 \mathrm{a}$ & $86.29 a$ & $3.88 \mathrm{a}$ & $4.13 \mathrm{a}$ & $2,974 a$ & $2,960 \mathrm{a}$ \\
\hline LSD (5\%) & 2.08 & 1.31 & 5.67 & 5.90 & 0.43 & 1.40 & 0.09 & 0.06 & 227 & 212 \\
\hline \multicolumn{11}{|l|}{ Inoculation } \\
\hline With Azospirillum & 55.62 & $54.26 \mathrm{a}$ & 88.38 & $76.00 \mathrm{a}$ & $84.85 a$ & $86.61 \mathrm{a}$ & $3.90 \mathrm{a}$ & $4.14 \mathrm{a}$ & 2,996 & 3,007 \\
\hline Without Azospirillum & 55.63 & $53.39 \mathrm{a}$ & 92.40 & $75.33 \mathrm{a}$ & $84.70 \mathrm{a}$ & $86.82 \mathrm{a}$ & $3.88 \mathrm{a}$ & $4.15 \mathrm{a}$ & 2,937 & 2,883 \\
\hline$\underline{\operatorname{LSD}}(5 \%)$ & 2.08 & 1.31 & 5.67 & 5.90 & 0.43 & 1.40 & 0.09 & 0.06 & 227 & 212 \\
\hline Overall mean & 55.63 & 53.82 & 90.39 & 75.67 & 84.78 & 86.71 & 3.89 & 4.15 & 2,966 & 2,945 \\
\hline Coefficient of variation $(\%)$ & 7.15 & 4.64 & 14.02 & 14.92 & 1.15 & 3.61 & 5.00 & 3.36 & 17.12 & 16.08 \\
\hline
\end{tabular}

${ }^{(1)}$ Means followed by equal letters, in the columns, do not differ by Tukey's test, at 5\% probability. LSD, lower significant difference. 
in wheat according to the $\mathrm{N}$ rates: Theago et al. (2014) reported an increase with a rate up to $200 \mathrm{~kg} \mathrm{ha}^{-1} \mathrm{~N}$, and Teixeira Filho et al. (2010) verified an increase up to $147 \mathrm{~kg} \mathrm{ha}^{-1} \mathrm{~N}$. This characteristic is attributed to the increase in the chlorophyll concentration promoted by the increased availability of total $\mathrm{N}$ in the vegetative part of the wheat (Figure $2 \mathrm{~F}$ and $\mathrm{G}$ ).

In the 2014 harvest, there was a significant interaction between the $\mathrm{N}$ rates and inoculation with $A$. brasilense in terms of the number of spikes per meter(Table 4). At rates of 150 and $200 \mathrm{~kg} \mathrm{ha}^{-1} \mathrm{~N}$, the non-inoculated treatments showed a higher number of spikes per meter. There was an adjustment to an increasing linear function for $\mathrm{N}$ rates in the non-inoculated treatments and an adjustment to a quadratic function in the inoculated treatments, with a point of maximum rate at $99.5 \mathrm{~kg} \mathrm{ha}^{-1} \mathrm{~N}$ (Figure $3 \mathrm{C}$ ). However, the $\mathrm{N}$ rates individually affected the number of spikes per meter in 2015 (Table 2), with an adjustment to a quadratic function for levels of up to $110 \mathrm{~kg} \mathrm{ha}^{-1} \mathrm{~N}$ (Figure $3 \mathrm{D}$ ). These results indicate that inoculation with $A$. brasilense alone or with high levels of $\mathrm{N}$ does not affect the number of spikes per meter. However, Teixeira Filho et al. (2007) observed that increasing N rates in the form of urea and no bacterial inoculation significantly affected the number of spikes per meter for wheat. The increased tillering, with the production of more spikes per meter due to the increase in $\mathrm{N}$ rates (Figure $3 \mathrm{C}$ and $\mathrm{D}$ ), explains in part the increase in crop yield.

Conventional urea and NBPT provided similar results for production components and grain yield of wheat (Tables 1 and 2) regardless of the inoculation with $A$. brasilense. Similarly, Megda et al. (2009), Teixeira Filho et al. (2010), and Theago et al. (2014) found no difference in the efficiency of $\mathrm{N}$ sources in the grain yields of irrigated wheat with satisfactory conditions of soil moisture in the Cerrado region.

Table 3. Interaction between inoculation and $\mathrm{N}$ rates $(0,50$, 100,150 , and $200 \mathrm{~kg} \mathrm{ha}^{-1}$ ) determined by the analysis of variance of the leaf chlorophyll index of wheat (Triticum aestivum) in 2014(1).

\begin{tabular}{lccccc}
\hline Inoculation & \multicolumn{5}{c}{ Leaf chlorophyll index (LCI) } \\
\cline { 2 - 6 } & 0 & 50 & 100 & 150 & 200 \\
\hline With Azospirillum & $47.95 \mathrm{a}$ & $52.96 \mathrm{a}$ & $55.97 \mathrm{a}$ & $59.79 \mathrm{a}$ & $61.41 \mathrm{a}$ \\
Without Azospirillum & $51.79 \mathrm{a}$ & $56.86 \mathrm{a}$ & $56.36 \mathrm{a}$ & $57.74 \mathrm{a}$ & $54.42 \mathrm{~b}$ \\
\hline
\end{tabular}

${ }^{(1)}$ Means followed by equal letters, in the columns, do not differ by Tukey's test, at 5\% probability. Lower significant difference (LSD), at 5\% probability, was 4.65 .
Prando et al. (2012) evaluated urea, urea + NBPT, and coated urea in a temperate climate and found no changes in the yield, grain mass, number of spikes per square meter, and plant height.

The interaction between the $\mathrm{N}$ rates and inoculation with $A$. brasilense was significant for wheat grain yield in 2014 and 2015 (Table 5). In 2014, at a rate of $150 \mathrm{~kg} \mathrm{ha} \mathrm{h}^{-1} \mathrm{~N}$, the grain yield of the inoculated treatment was higher than that of the non-inoculated treatment. The wheat grain yield in the 2014 harvest increased linearly with the $\mathrm{N}$ rates without inoculation and was adjusted to a quadratic function for the inoculated treatments, with a positive response for a rate of up to $139 \mathrm{~kg} \mathrm{ha}^{-1} \mathrm{~N}$ (Figure $3 \mathrm{E}$ ). In 2015, the grain yield of the inoculated treatment was higher than that of the non-inoculated treatment for a rate of $100 \mathrm{~kg} \mathrm{ha}^{-1} \mathrm{~N}$ (Table 5). The grain yield in the 2015 harvest was adjusted to a quadratic function for $\mathrm{N}$ rates in inoculated and non-inoculated treatments, with a positive response for rates of 142 and $134 \mathrm{~kg} \mathrm{ha}^{-1} \mathrm{~N}$,

Table 4. Interaction between inoculation and $\mathrm{N}$ rates $(0,50$, 100,150 , and $200 \mathrm{~kg} \mathrm{ha}^{-1}$ ) determined by the analysis of variance of the number of wheat (Triticum aestivum) spikes per meter in $2014^{(1)}$.

\begin{tabular}{lccccc}
\hline Inoculation & \multicolumn{5}{c}{ Number of spikes per meter } \\
\cline { 2 - 6 } & 0 & 50 & 100 & 150 & 200 \\
\hline With Azospirillum & $82.75 \mathrm{a}$ & $90.38 \mathrm{a}$ & $94.25 \mathrm{a}$ & $89.75 \mathrm{~b}$ & $84.75 \mathrm{~b}$ \\
Without Azospirillum & $79.25 \mathrm{a}$ & $81.50 \mathrm{a}$ & $95.75 \mathrm{a}$ & $106.00 \mathrm{a}$ & $99.50 \mathrm{a}$ \\
\hline
\end{tabular}

${ }^{(1)}$ Means followed by equal letters, in the columns, do not differ by Tukey's test, at 5\% probability. Lower significant difference (LSD), at 5\% probability, was 12.69 spikes per meter.

Table 5. Interaction between inoculation and $\mathrm{N}$ rates $(0$, $50,100,150$, and $\left.200 \mathrm{~kg} \mathrm{ha}^{-1}\right)$ determined by the analysis of variance of the wheat (Triticum aestivum) grain yield in 2014 and $2015^{(1)}$.

\begin{tabular}{lccccc}
\hline Inoculation & \multicolumn{5}{c}{ Grain yield $\left(\mathrm{kg} \mathrm{ha}^{-1}\right)$} \\
\cline { 2 - 5 } & 0 & 50 & 100 & 150 & 200 \\
\hline \multirow{5}{*}{2014 crop season } \\
With Azospirillum & $2,196 \mathrm{a}$ & $2,916 \mathrm{a}$ & $3,205 \mathrm{a}$ & $3,544 \mathrm{a}$ & $3,119 \mathrm{a}$ \\
Without Azospirillum & $2,342 \mathrm{a}$ & $3,092 \mathrm{a}$ & $3,060 \mathrm{a}$ & $2,989 \mathrm{~b}$ & $3,203 \mathrm{a}$ \\
\hline & \multicolumn{5}{c}{2015 crop season } \\
With Azospirillum & $1,671 \mathrm{a}$ & $3,036 \mathrm{a}$ & $3,663 \mathrm{a}$ & $3,167 \mathrm{a}$ & $3,497 \mathrm{a}$ \\
Without Azospirillum & $2,141 \mathrm{a}$ & $3,018 \mathrm{a}$ & $3,063 \mathrm{~b}$ & $3,166 \mathrm{a}$ & $3,029 \mathrm{a}$ \\
\hline
\end{tabular}

${ }^{(1)}$ Means followed by equal letters, in the columns, do not differ by Tukey's test, at 5\% probability. Lower significant difference (LSD), at 5\% probability, was 508 and $474 \mathrm{~kg} \mathrm{ha}^{-1}$ in the 2014 and 2015 crop seasons, respectively. 
respectively (Figure $3 \mathrm{~F}$ ). Compared with the control (without $\mathrm{N}$ ), the optimum $\mathrm{N}$ rate in the inoculated treatment provided higher grain yield (391 kg ha-1) than the best $\mathrm{N}$ rate in the non-inoculated treatment, a $7 \%$ yield increase in the second crop year.

The inoculation with $A$. brasilense associated with $\mathrm{N}$ rates of $140 \mathrm{~kg} \mathrm{ha}^{-1}$ provided the maximum yield in the evaluated crops. However, with no inoculation,
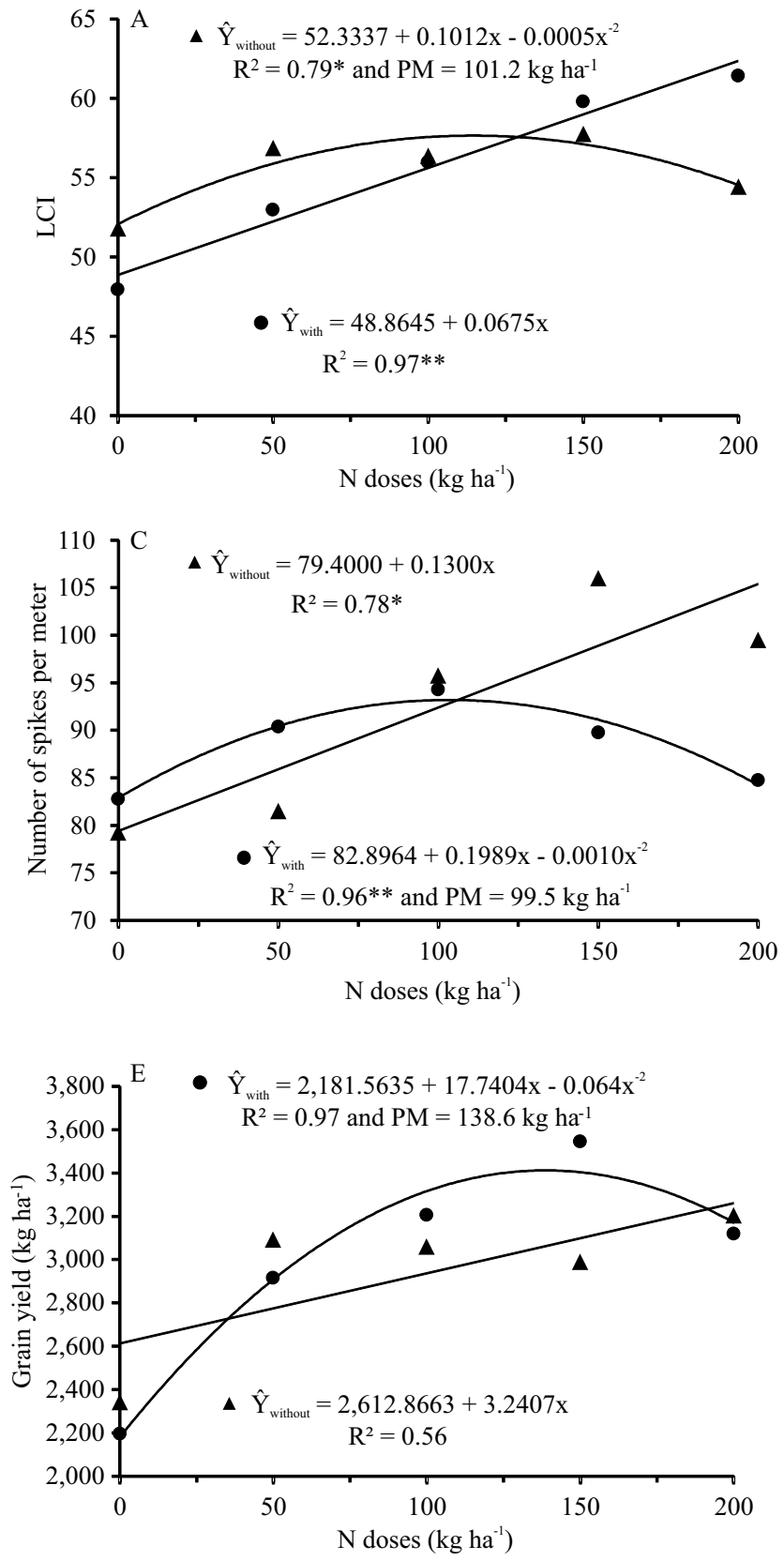

the magnitude of the crop responses to the $\mathrm{N}$ rates was greater because the adjustment to the increasing linear function in 2014. Increases in the efficiency of $\mathrm{N}$ fertilization associated with inoculation with A. brasilense were also reported by Galindo et al. (2016) in corn crops in the Cerrado. These authors also found that inoculation increased the LCI and phosphorus concentration in the leaves. According to Dobbelaere
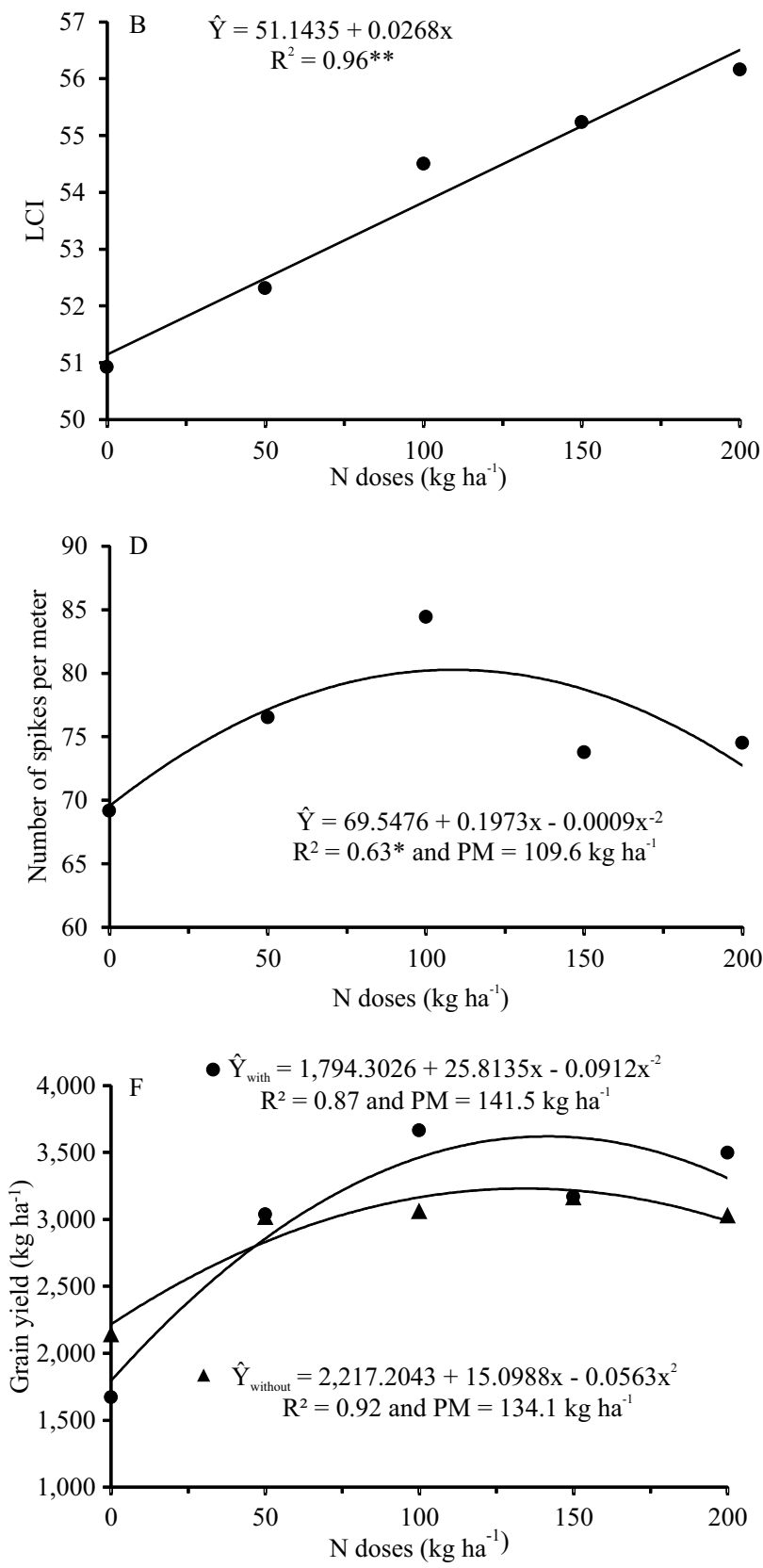

Figure 3. Interaction between $\mathrm{N}$ rates and inoculation with Azospirillum brasilense in terms of leaf chlorophyll index (LCI) in 2014 (A) and 2015 (B), as affected by N rates; number of spikes per meter in 2014 (C) and 2015 (D), as affected by N rates; and grain yield in 2014 (E) and $2015(\mathrm{~F}) . * *$ and *Significant at 1 and 5\% probability, respectively. 
et al. (2003), positive responses to inoculation with $A$. brasilense are obtained even when the crops are grown in soils with a high $\mathrm{N}$ content, which indicates that the plant responses do not occur only because of BNF, but also because of the production of plant growth hormones, including cytokinin, gibberellin, and indoleacetic acid.

With regard to grain yield, several authors reported a positive response to $\mathrm{N}$ fertilization in wheat (Cazetta et al., 2007; Teixeira Filho et al., 2007, 2008, 2010; Povh et al., 2008). The maximum grain yield was observed at $\mathrm{N}$ rates of $78 \mathrm{~kg} \mathrm{ha}^{-1}$ (Cazetta et al., 2007), $90 \mathrm{~kg} \mathrm{ha}^{-1}$ (Teixeira Filho et al. 2007, 2008), and $120 \mathrm{~kg} \mathrm{ha}^{-1}$ (Teixeira Filho et al., 2010) in similar climate conditions for the cultivation of wheat as a winter crop in the lowaltitude Cerrado region. These differences in the $\mathrm{N}$ rates that provide the maximum wheat grain yield are due to the distinct $\mathrm{N}$ requirement of each cultivar and the variation in environmental conditions.

Lemos et al. (2013) evaluated five wheat cultivars (CD 104, CD 108, CD 119, CD 120, and CD 150) with and without inoculation with $A$. brasilense associated with different $\mathrm{N}$ levels and observed that the response to inoculation was satisfactory in cases in which inoculation was associated with $\mathrm{N}$ fertilization. In the present work, a similar result was observed using $\mathrm{N}$ rates of 150 and $100 \mathrm{~kg} \mathrm{ha}^{-1}$ in the first and second crop years, respectively (Table 5). Therefore, inoculation with $A$. brasilense in addition to the supply of $\mathrm{N}$ in the form of urea or NBPT increased the yield of irrigated wheat grains in the Cerrado region (Figure $3 \mathrm{E}$ and $\mathrm{F}$ ), although these treatments alone were not sufficiently effective to replace $\mathrm{N}$ fertilization. Conversely, Ferreira et al. (2014) inoculated $A$. brasilense in plant leaves and used $\mathrm{N}$ fertilization of wheat plantations in the Cerrado region and found that bacterial inoculation did not affect the plant height, number of spikes per square meter, number of grains per spike, hectoliter mass, mass of 1,000 grains, and grain yield. Similarly, Nunes et al. (2015) evaluated the inoculation of $A$. brasilense in soils with high and low availability of N, and Galindo et al. (2015) evaluated the periods of application of $A$. brasilense on plant leaves and found that bacterial inoculation did not affect production components and wheat grain yield in the Cerrado region with the application of $100 \mathrm{~kg} \mathrm{ha}^{-1}$ of $\mathrm{N}$ in the form of urea. However, it is notable that the affinity between the cultivars and the strains of diazotrophic bacteria may vary and affect the outcome of inoculation.

\section{Conclusions}

1. The increase in the $\mathrm{N}$ rates positively affects spike length, number of spikelets per spike, number of grains per spike, number of spikes per meter, $\mathrm{N}$ accumulation in the straw, leaf chlorophyll content, and grain yield of irrigated wheat (Triticum aestivum), regardless of the use of NBPT urease inhibitor with conventional urea.

2. The inoculation with Azospirillum brasilense alone does not affect production components and grain yield, although it increases the $\mathrm{N}$ content in wheat straw.

3. The inoculation with $A$. brasilense, in addition to the application of $140 \mathrm{~kg} \mathrm{ha}^{-1} \mathrm{~N}$, provides the highest grain yield of irrigated wheat cropped after corn in low-altitude Cerrado.

\section{Acknowledgments}

To Coordenação de Aperfeiçoamento de Pessoal de Nível Superior (Capes), for financial support.

\section{References}

ACOMPANHAMENTO DA SAFRA BRASILEIRA [DE] GRÃOS: safra 2015/2016: primeiro levantamento, Brasília, v.1, n.1, out. 2015. 148p. Available at: $<$ http://www.conab.gov. br/OlalaCMS/uploads/arquivos/15_10_09_17_45_57_boletim graos_outubro_2015_novo.pdf>. Accessed on: Oct. 122015.

BARASSI, C.A.; SUELDO, R.J.; CREUS, C.M.; CARROZZI, L.E.; CASANOVAS, E.M.; PEREYRA, M.A. Potencialidad de Azospirillum en optimizar el crecimiento vegetal bajo condiciones adversas. In: CASSÁN, F.D.; GARCIA DE SALAMONE, I. (Ed.). Azospirillum sp.: cell physiology, plant interactions and agronomic research in Argentina. Argentina: Asociación Argentina de Microbiologia, 2008. p.49-59.

BASHAN, Y.; HOLGUIN, G.; DE-BASHAN, L.E. Azospirillumplant relationships: physiological, molecular, agricultural, and environmental advances (1997-2003). Canadian Journal of Microbiology, v.50, p.521-577, 2004. DOI: 10.1139/w04-035.

CANTARELlA, H.; RAIJ, B. van; CAMARGO, C.E.O. Cereais. In: RAIJ, B. van; CANTARELLA, H.; QUAGGIO, J.A.; FURLANI, A.M.C. Recomendações de adubação e calagem para o Estado de São Paulo. 2.ed. rev. e atual. Campinas: Instituto Agronômico, 1997. 285p. (IAC. Boletim técnico, 100).

CANTARELlA, H.; TRIVELIN, P.C.O.; CONTIN, T.L.M.; DIAS, F.L.F.; ROSSETTO, R.; MARCELINO, R.; COIMBRA, R.B.; QUAGGIO, J.A. Ammonia volatilisation from urease inhibitor-treated urea applied to sugarcane trash blankets. Scientia Agricola, v.65, p.397-401, 2008. DOI: 10.1590/S010390162008000400011. 
CAZETTA, D.A.; FORNASIERI FILHO, D.; ARF, O. Resposta de cultivares de trigo e triticale ao nitrogênio no sistema de plantio direto. Científica, v.35, p.155-165, 2007. DOI: 10.15361/1984-5529.2007v35n2p155+-+165.

DOBBELAERE, S.; VANDERLEYDEN, J.; OKON, Y. Plant growth-promoting effects of diazotrophs in the rhizosphere. Critical Reviews of Plant Sciences, v.22, p.107-149, 2003. DOI: 10.1080/713610853.

FERREIRA, D.F. Sisvar: a computer statistical analysis system. Ciência e Agrotecnologia, v.35, p.1039-1042, 2011. DOI: 10.1590/S1413-70542011000600001.

FERREIRA, J.P.; ANDREOTTI, M.; ARF, O.; KANEKO, F.H.; NASCIMENTO, V.; SABUNDJIAN, M.T. Inoculação com Azospirillum brasilense e nitrogênio em cobertura no trigo em região de Cerrado. Tecnologia e Ciência Agropecuária, v.8, p.27-32, 2014.

FRANK, A.B.; BAUER, A. Temperature, nitrogen and carbon dioxide effects on spring wheat development and spikelet numbers. Crop Science, v.36, p.659-665, 1996. DOI: 10.2135/ cropsci1996.0011183X003600030024x.

GALINDO, F.S.; LUDKIEWICZ, M.G.Z.; BELLOTE, J.L.M.; SANTINI, J.M.K.; TEIXEIRA FILHO, M.C.M.; BUZETTI, S. Épocas de inoculação com Azospirillum brasilense via foliar afetando a produtividade da cultura do trigo irrigado. Tecnologia e Ciência Agropecuária, v.9, p.43-48, 2015.

GALINDO, F.S.; TEIXEIRA FILHO, M.C.M.; BUZETTI, S.; SANTINI, J.M.K.; ALVES, C.J.; NOGUEIRA, L.M.; LUDKIEWICZ, M.G.Z.; ANDREOTTI, M. BELLOTTE, J.L.M. Corn yield and foliar diagnosis affected by nitrogen fertilization and inoculation with Azospirillum brasilense. Revista Brasileira de Ciência do Solo, v.40, p.e0150364, 2016. DOI: 10.1590/18069657rbcs20150364.

HUNGRIA, M. Inoculação com Azospirillum brasilense: inovação em rendimento a baixo custo. Londrina: Embrapa Soja, 2011. 37p. (Embrapa Soja. Documentos, 325).

HUNGRIA, M.; CAMPO, R.J.; SOUZA, E.M. S.; PEDROSA, F.O. Inoculation with selected strains of Azospirillum brasilense and A. lipoferum improves yields of maize and wheat in Brazil. Plant and Soil, v.331, p.413-425, 2010. DOI: 10.1007/s11104-0090262-0.

LARA CABEZAS, W.A.R.; TRIVELIN, P.C.O.; KORNDÖRFER, G.H.; PEREIRA, S. Balanço da adubação nitrogenada sólida e fluida de cobertura na cultura de milho, em sistema plantio direto no Triângulo Mineiro (MG). Revista Brasileira de Ciência do Solo, v.24, p.363-376, 2000. DOI: 10.1590/S010006832000000200014.

LEMOS, J.M.; GUIMARÃES, V.F.; VENDRUSCOLO, E.C.; SANTOS, M.F.; OFFEMANN, L.C. Resposta de cultivares de trigo à inoculação de sementes com Azospirillum brasilense, e à adubação nitrogenada em cobertura. Científica, v.41, p.189-198, 2013.

MALAVOLTA, E.; VITTI, G.C.; OLIVEIRA, S.A. de. Avaliação do estado nutricional das plantas: princípios e aplicações. 2.ed. Piracicaba: Potafos, 1997. 319p.
MEGDA, M.M.; BUZETTI, S.; ANDREOTTI, M.; TEIXEIRA FILHO, M.M.C.; VIEIRA, M.X. Resposta de cultivares de trigo ao nitrogênio em relação às fontes e épocas de aplicação sob plantio direto e irrigação por aspersão. Ciência e Agrotecnologia, v.33, p.1055-1060, 2009. DOI: 10.1590/S1413-70542009000400016.

NUNES，P.H.M.P.; AQUINO, L.A.; SANTOS, L.P.D. dos; XAVIER, F.O.; DEZORDI, L.R.; ASSUNÇÃO, N.S. Produtividade do trigo irrigado submetido à aplicação de nitrogênio e à inoculação com Azospirillum brasilense. Revista Brasileira de Ciência do Solo, v.39, p.174-182, 2015. DOI: 10.1590/01000683rbcs20150354.

PIETRO-SOUZA, W.; BONFIM-SILVA, E.M.; SCHLICHTING, A.F.; SILVA, M. de C. Desenvolvimento inicial de trigo sob doses de nitrogênio em Latossolo Vermelho de Cerrado. Revista Brasileira de Engenharia Agrícola e Ambiental, v.17, p.575580, 2013. DOI: $10.1590 /$ S1415-43662013000600001

POVH, F.P.; MOLIN, J.P.; GIMENEZ, L.M.; PAULETTI, V.; MOLIN, R.; SALVI, J.V. Comportamento do NDVI obtido por sensor ótico ativo em cereais. Pesquisa Agropecuária Brasileira, v.43, p.1075-1083, 2008. DOI: 10.1590/S0100204X2008000800018.

PRANDO, A.M.; ZUCARELI, C.; FRONZA, V.; BASSOI, M.C.; OLIVEIRA, F.A. de. Formas de ureia e doses de nitrogênio em cobertura no desempenho agronômico de genótipos de trigo. Semina: Ciências Agrárias, v.33, p.621-632, 2012. DOI: 10.5433/1679-0359.2012v33n2p621.

RAIJ, B. van; ANDRADE, J.C. de; CANTARELLA, H.; QUAGGIO, J.A. (Ed.). Análise química para avaliação da fertilidade de solos tropicais. Campinas: IAC, 2001. 285p.

RODRIGUES, L.F.O.S.; GUIMARÃES, V.F.; SILVA, M.B. da; PINTO JUNIOR, A.S.; KLEIN, J.; COSTA, A.C.P.R. da. Características agronômicas do trigo em função de Azospirillum brasilense, ácidos húmicos e nitrogênio em casa de vegetação. Revista Brasileira de Engenharia Agrícola e Ambiental, v.18, p.31-37, 2014. DOI: 10.1590/S1415-43662014000100005.

SANTOS, H.G. dos; JACOMINE, P.K.T.; ANJOS, L.H.C. dos; OLIVEIRA, V.A. de; LUBRERAS, J.F.; COELHO, M.R.; ALMEIDA, J.A. de; CUNHA, T.J.F.; OLIVEIRA, J.B. de. Sistema brasileiro de classificação de solos. 3.ed. rev. e ampl. Brasília: Embrapa, 2013. 353p.

TEIXEIRA FILHO, M.C.M.; BUZETTI, S.; ALVAREZ, R. de C.F.; FREITAS, J.G. de; ARF, O.; SÁ, M.E. de. Resposta de cultivares de trigo irrigado por aspersão ao nitrogênio em cobertura na região do Cerrado. Acta Scientiarum. Agronomy, v.29, p.421-425, 2007. DOI: 10.4025/actasciagron.v29i3.471

TEIXEIRA FILHO, M.C.M.; BUZETTI, S.; ALVAREZ, R. de C.F.; FREITAS, J.G. de; ARF, O.; SÁ, M.E. Desempenho agronômico de cultivares de trigo em resposta a população de plantas e a adubação nitrogenada. Científica, v.36, p.97-106, 2008.

TEIXEIRA FILHO, M.C.M.; BUZETTI, S.; ANDREOTTI, M.; ARF, O.; BENETT, C.G.S. Doses, fontes e épocas de aplicação de nitrogênio em trigo irrigado em plantio direto. Pesquisa Agropecuária Brasileira, v.45, p.797-804, 2010. DOI: 10.1590/ S0100-204X2010000800004. 
THEAGO, E.Q.; BUZETTI, S.; TEIXEIRA FILHO, M.C.M.; ANDREOTTI, M.; MEGDA, M.M.; BENETT, C.G.S. Doses, fontes e épocas de aplicação de nitrogênio influenciando teores de clorofila e produtividade do trigo. Revista Brasileira de Ciência do Solo, v.38, p.1826-1835, 2014. DOI: 10.1590/S010006832014000600017.
VALDERRAMA, M.; BUZETTI, S.; TEIXEIRA FILHO, M.C.M.; BENETT, C.G.S.; ANDREOTTI, M. Adubação nitrogenada na cultura do milho com ureia revestida por diferentes fontes de polímeros. Semina: Ciências Agrárias, v.35, p.659-670, 2014. DOI: $10.5433 / 1679-0359.2014 v 35 n 2 p 659$.

$\overline{\text { Received on January 30, } 2016 \text { and accepted on September 16, } 2016}$ 